\title{
Kairos moments and prophetic witness: Towards a prophetic ecclesiology
}

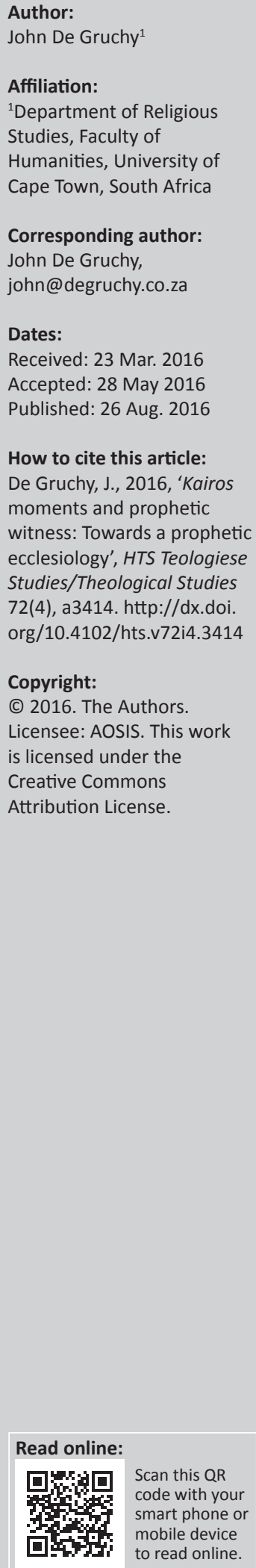

The thirtieth anniversary of the publication of the Kairos Document was celebrated in August 2015. This was the most radical of several theological declarations issued by Christians during the struggle against apartheid. Arguing that theology itself had become a site of that struggle, it rejected 'state theology', which gave legitimacy to apartheid, and 'church theology' which promoted reconciliation without justice as its pre-requisite. Against these, it presented a 'prophetic theology' as a challenge to the churches in response to what was perceived as a kairos moment. Since then the Kairos Document has inspired a global movement in which its social analysis and understanding of prophetic theology has been adopted in a variety of contexts, most notably in the Kairos-Palestine Document (2009). In reflecting on the significance of this global kairos movement, I firstly examine the meaning of 'prophecy' and 'prophetic theology', arguing that 'prophetic theology' is in continuity with the message of the Hebrew prophets and the ministry and mission of Jesus. Secondly, I examine the use of the term kairos to describe historical turning points which demand such a prophetic theological response. Thirdly, I address the need for an ecumenical prophetic ecclesiology that foregrounds the responsibility of the church to discern and understand those God-given kairos moments in history that demand a prophetic response.

\section{Prophetic theology}

The notion that Christian theology is a site of struggle has its roots in the Hebrew Bible where different theological trajectories weave their way through the narrative, sometimes complementing each other, but often in conflict despite the attempts of redactors to smooth over the fault lines. Walter Brueggemann speaks to this when he describes Old Testament theology as an ongoing dispute within its testimony to the God of Abraham and its advocacy of trust in God's promises. He highlights the cross-examination of the text, which is not only pursued by critics from outside, but often inside (Brueggemann 1997:317-332). The dominant view of God as trustworthy, he tells us, is often deconstructed by prophets not for the sake of debunking faith, but in order to provide an alternative, authentic, rhetorically imaginative, and subversive understanding of the reign of God within history characterised by divine justice and pathos in solidarity with those who suffer (Heschel 1962:195-231).

Prophecy in the Old Testament is a complex phenomenon (Brueggemann 1997:622). Even the words we translate 'prophet' and 'prophecy' are variously used (Brown 1978:74-89). There were bands of wandering ecstatic prophets in Israel before the emergence of the prophets of justice to whom Brueggemann refers. There were also cultic prophets and priests who were forerunners of the later post-exilic prophets Zechariah, Nahum and Haggai whose major concern was national rebirth through obedience to the Torah. But the prophets Brueggemann has in mind are the eighth century BCE pre-exilic prophets, chiefly Amos, Isaiah, Jeremiah, Micah and Hosea, who called Israel to repentance and the pursuit of social justice, or face disaster (Heschel 1962:299-306; von Rad 1972:145-156). These are the prophets to whom I will refer when using the term with reference to the Old Testament.

These prophets did not speak in balanced theological generalisations but spoke to the actuality of their situation. They uttered what Martin Buber called the 'concrete reality of the word' (Buber 1960:96). However reluctantly proclaimed, their message was not intended to convince their hearers of abstract theological truth but 'to disrupt, destabilise, and invite to alternative perceptions of reality' (Brueggemann 1997:625-626). Aware of Israel's plight and the disaster that faced her, they did not mince their words of judgment, but offered imaginative 'images of new possibility' that were equally subversive of the status quo (Brueggemann 1997:625-626). That is why the prophets were persecuted, condemned for treason, and killed, as Jesus observed and anticipated in terms of his own ministry and fate (Lk 11:49-50). 
In contrast there were court prophets who supported the kings. The fact that they were often castigated by the prophets as 'false' did not mean they were 'shameless charlatans' (Heschel 1962:482), but as far as the prophets were concerned, they were false witnesses, proclaiming peace when there was none, and giving divine legitimation to unjust policies and idolatrous practices. The prophets also confronted the priests who mediated the relationship between Yahweh and Israel, wanting to rid the cult of abuses so that justice could flow down like a mighty river.

As in the Old Testament, so in the New, the words 'prophet' and 'prophecy' are used in different ways (Aune 1983). The gift of prophecy usually refers to charismatic preachers who helped guide the churches in their life and mission. But when the prophets are referred to, the writers invariably have the major prophets of the Old Testament in mind. It was the word of these prophets that Jesus claimed to fulfil (Mt 5:17). Jesus also claimed to possess the Spirit in a way associated with being a prophet (Dunn 1975:82-83). This did not mean either for him or his followers that 'he simply took his place as a link in the chain of the many Old Testament messengers of God' (Jeremias 1971:80). There is a finality to his revelation unlike that of the prophets who anticipated his coming, and a clear sense in the gospel story of a transition from the 'prophetic to the more-thanprophetic'. But this transition does not take anything away from his prophetic self-understanding or understanding of his mission (Dunn 1975:84).

Evangelists and apologists tried to prove that Jesus was the Messiah on the basis of predictive proof texts from the Old Testament, but this is not what is meant by Jesus fulfilling the prophets. The prophets' calling was not to predict but to promise that the Messiah who would inaugurate God's reign would be a 'suffering servant' who came to 'proclaim liberty to captives ... and the year of the Lord's favour'. It was this promise Jesus claimed to fulfil (Luke 4:16-21). But this did not mean that their witness came to an end, that they had, to put it colloquially, done their job. On the contrary, Jesus affirmed the abiding justice message of the prophets by embodying the judgment and hope they proclaimed (Jeremias 1971:82, 85). In Edward Schillebeeckx's words, he 'revived and repeated what had most powerfully impelled the great prophets' (Schillebeeckx 1979:446). In other words, Jesus recapitulated their witness, but did so within a new framework beyond the tribal, giving it an even greater status and significance for the world as a whole. And just as his fulfilment of the Law meant going beyond it, as in his comments on the Sabbath or when he declared 'but I say unto you', so his fulfilment of the prophets made their message perennial and global in scope.

These, then, were the prophets and this was the prophetic tradition that was in mind when the South African Kairos Document was drafted in 1985 during the first state of emergency. This is evident from the outset: 'Our present KAIROS calls for a response from Christians that is biblical, spiritual, pastoral and, above all prophetic' (Kairos Document 1986:17). The kairos theologians were not proposing something new; they were discerning 'the signs of the times (kairos)' and challenging the church to respond in obedience to the witness of the prophets and the testimony of Jesus. The Kairos, they declared, impelled them 'to return to the Bible and to search the Word of God for a message that is relevant to what we are experiencing in South Africa today' (Kairos Document 1986:17), and therefore compelled them 'to analyse more carefully the different theologies in our Churches and to speak out more clearly and boldly about the real significance of these theologies'. In doing so, they rejected 'State Theology', which gave legitimacy to apartheid, and 'Church Theology', which promoted reconciliation without justice as its pre-requisite.

For the kairos theologians, this theological struggle, reflected that in the Old Testament between the prophets, false prophets, kings and priests, was equally evident in the New Testament narrative, namely in Jesus' confrontation with the ruling and religious elites of his day, which led to his inevitable death like the prophets before him. But this theological conflict did not end there; it continued through subsequent centuries within Christendom, as kings, priests and prophets locked horns on occasions too numerous to document here. And, to fast forward, the story of conflict between 'prophet, priest and king' continued in Southern Africa from the beginning of colonial history.

The controversies among colonial authorities, settler churches and a handful of missionaries who felt compelled to represent the interests of indigenous people is well known, as is the story of Ntsikana, the Xhosa prophet, P.J. Mzimba and others like them (De Gruchy 2004:1-50). But theological conflict along these lines erupted most sharply during the church struggle against apartheid (de Gruchy 1985:16-26). While this had more to do with politics and ethics than dogmatics, these can hardly be separated in doing theology in response to historical reality. The theological struggle against apartheid was not about the two-natures of Christ, episcopacy or the eucharist, but racial ideology, political oppression and social justice. This was the framework within which Christology, ecclesiastical authority and the Lord's Supper had to be understood, contested, and in which heresy was defined. As prophets have always insisted, what is politically and morally wrong cannot be dogmatically right.

The prophetic tradition which culminates in the ministry and mission of Jesus provides the raw material for prophetic theology, just as prophetic theology in turn critically retrieves that tradition in order to enable prophetic witness in changing historical contexts. Its methodology is critical theological and biblical reflection informed by social analysis and ecclesial praxis, or 'seeing, judging, and acting' (Kairos Document 1986:17). As such, prophetic theology does not emerge in the first instance from academic study, but from participation in the struggle for justice. Prophetic theologians, to use Antonio Gramsci's term are 'organic intellectuals' (Gramsci 1971:6-14). Their aim is not to provide a balanced, 
carefully constructed and appropriately nuanced theological system, which would quench the spirit of prophecy, but to enable prophetic witness to take place within the struggles that arise in kairos moments. While some prophetic theology may find expression in academic treatises, it is mostly expressed in what Karl Barth referred to as 'irregular dogmatics' (Barth 1975:275) - workshop papers, letters to the press and government, conference resolutions, tracts, pamphlets and sermons. The Kairos Document, although, drafted by trained theologians, was a 'prophetic tract' rather than a 'systematic treatise', produced in conversation with activists in the townships. In that sense, it was, as some kairos theologians insisted, also a 'peoples' theology' (Nolan 1994:212-218).

This raises an important question and takes our discussion a step further, for who is 'the people' to whom the prophets and prophetic theologians listen? The message of the Hebrew prophets was not arrived at through a democratic process, but neither did the Word of the Lord drop out of the sky. The prophets were nurtured in a tradition that stretched back at least to Moses and Elijah. Yet it was only as they listened to the cries of the widows and orphans, the aliens and poor that they 'heard the Word of the Lord' speak directly to the situation that confronted both them and Israel. The prophets, in other words, 'saw things from below', to use Dietrich Bonhoeffer's phrase (Bonhoeffer 2010:52), or they 'took a preferential option for the poor' to use that of the liberation theologians. In doing so, they discerned the kairos moment that demanded a prophetic response.

\section{Kairos moments}

The term kairos was first used in modern theology by Paul Tillich to describe the situation facing Germany after the First World War (Tillich 1957:32-54). ${ }^{1}$ Tillich chose the word to 'express the feeling ... that a moment of history had appeared which was pregnant with a new understanding of history and life' (Tillich 1963:369). He spoke further about this consciousness as 'being inwardly grasped by the fate and destiny of the time' found in the 'passionate longing of the masses'. This is then clarified and takes 'form in small circles of conscious intellectual and spiritual concern' and finally gains 'power in the prophetic word' (Tillich 1957:48). In other words, while 'the people' who were suffering may be conscious of a moment in history that had to be grasped, it was the 'organic intellectuals' or 'organic theologians' who gave expression to their longing.

Tillich distinguished between the unique kairos of the coming of the Kingdom of God in Jesus, and the kairoi which occur throughout history at particular moments and are discerned as such by prophets who 'read the signs of the times' and make the connection between them and God's Kairos. In the post-First World War context Tillich also discerned the hand of God in the response of the Social Democratic Movement to the kairos (Tillich 1963:369). But he did not, as Walter Horton later wrote, 'suspend the Christian duty of prophetic criticism 1.This was first published in Die Tat vol. 14, no. 5, in 1922. against the 'demonic elements' in socialism' (Horton 1952:33). On the contrary, his usage was in continuity with the way in which kairos is understood in the New Testament:

The New Testament doctrine of kairos, to which the religious socialists gave a new application, is thoroughly prophetic and eschatological. It sees the 'fullness of time' (kairos) in Christ as a time of fulfillment, a time of judgment, and a time of promise yet to be fulfilled. (Horton 1952:32)

A decade later, one of Tillich's close colleagues, Emmanuel Hirsch, arguably the most brilliant German theologian of the time (Barth 1956:20), used kairos to positively describe Hitler's rise to power (Hirsch 1933). For Hirsch, as for Paul Althaus, another leading Lutheran theologian, 1933 was a kairos moment, initiated by God for saving the German Volk from the humiliation of Versailles, the failures of Weimar, and the poverty of the Great Depression (Ericksen 1985:150-162). Hitler was the new Luther ordained by God to rescue the Volk, and therefore his rise to power demanded a positive Christian response of wholehearted obedience in order that the church could serve the 'the German People', be renewed, stand united and prevail against secularism and communism (Scholder 1987:417-420). In this way, Hirsch gave intellectual leadership to the consciousness of 'the people' and provided the theological platform for die deutsche Christen movement which sought to control the Evangelical Church in support of Hitler. In reaction, Tillich abruptly ended their friendship and accused Hirsch's of abusing the term kairos to describe 'an idolatrous nationalism and racialism'. Hirsch, he declared, 'was a false prophet' (Tillich 1963:371).

As a young pastor in Switzerland prior to the First World War, Barth like Tillich was an active member of the Social Democratic Party (Barth \& Eduard 1964:28-29). Already in 1911 he had declared that 'Jesus is the movement for social justice, and the movement for social justice is Jesus in the present' (Barth 1976:19). For him, the church had to take the side of the working class in their struggle against capitalist overlords. This was 'the people' to whom the prophet of the Lord should listen. But like Tillich, Barth insisted that the social democratic movement was not beyond criticism, qualifying his equation of the movement with God's purposes in history by saying it was so only 'in the present' and not in any absolute sense.

However, by the time Barth drafted the Barmen Declaration (1934), he had categorically rejected the identification of any movement, whether nationalism or socialism, with the will of God. The Barmen Declaration rejected the theology of die deutsche Christen crafted by Hirsch point by point (Cochrane 1976:280-288). God does not reveal his sovereign will in the history of a Volk, nor can any nation be regarded as specially chosen by God to fulfil God's purposes. God's revelation in Jesus Christ is final and the only basis for our knowledge of God. The kairos facing the church in Germany was a Status Confessionis, a time for the 'true church' to confess its faith in Christ against the 'false church', die Volkskirche. Reflecting on this later, Barth wrote that the church becomes alienated from following Christ not only 'by the adoption of a particular 
philosophy or outlook as the norm for its understanding of the Word of God', but also when its ethics are controlled by a specific historical kairos (Barth 1958:667). That is, in his context, whether it is National Socialism or Democratic Socialism. In other words, on this matter, Barth distanced himself both from Tillich, with whom he was politically in agreement, and from Hirsch whom he opposed.

These responses to kairos moments in German history help us in critically reflecting back on the development of theology in South Africa during the past century in its varied responses to our historical context. Firstly, it is not difficult to draw parallels between the way in which leading Afrikaner theologians understood the rise to power of Afrikaner Nationalism and Hirsch's positive response to Hitler's 'election' to the rapturous applause of 'the people' in 1933. The election of the National Party in 1948 was equally a 'turning point' which signalled for Afrikaners emancipation at the hand of God. This was the stuff out of which 'state theology' in support of apartheid emerged. But it all began as a 'popular volk theology', a kairos theology premised on the belief that the Afrikaner volk, battered and bruised by the Anglo-Boer War, had a special role and destiny at the southern tip of Africa. ${ }^{2}$ As D.F. Malan, dominee and Afrikaner Nationalist leader put it, 'Afrikanerdom is not the work of men but the creation of God' (Moodie 1975:1).

Secondly, as in Germany so in South Africa, Barth's theology strongly influenced the attack on the theological foundations of this 'state theology' (Villa-Vicencio 1988a). Although not Barthian in any narrow sense, the Message to the People of South Africa, published in 1968 by the South African Council of Churches, was likened to the Barmen Declaration. In calling apartheid a 'false gospel' it unequivocally rejected apartheid as fundamentally un-Christian and a contradiction of the 'gospel of reconciliation'.

Thirdly, the publication of the Message exposed the racial divisions within the member churches of the SACC which were effectively, if not constitutionally, comprised of 'white' and 'black' sections despite their claim to be multiracial (De Gruchy 2004:40-50). White members understood reconciliation as having to do with individuals in relation to God and neighbour, not political policies. At most, it meant liberal reforms (Kairos Document 1986:9-16). This division between 'white' and 'black' churches within the SACC denominations became more sharply apparent with the emergence of Black Theology in the following years (De Gruchy 2004:144-183). And Black Theology, we must note, was a response to 'Black Consciousness', that is to the growing awareness among younger blacks led by Steve Biko, the organic intellectual of the movement, that the kairos had come to take their destiny into their own hands. In this way the Message and Black Theology laid bare what the Kairos Document would later call the 'church theology' of the 'white church'.

2.Of particular influence was the work of the philosopher H.G. Stoker and the theologian F.J.M Potgieter and the series of books they edited entitled Koers in die Krisis (Stellenbosch: Pro Ecclesia, 1935f).
Fourthly, the Belhar Confession (1982), which was more closely modelled on the Barmen Declaration than the Message, addressed the same problem but specifically within the Reformed family of churches (Cloete \& Smit 1984). Although political by implication, its primary focus was on the historic and constitutional racial divisions within the Reformed Church. As such, Belhar was a response to what was described as a status confessionis rather than a kairos, declaring apartheid theologically indefensible and church segregation an ecclesiological heresy (Bosch 1983 24-38). The Belhar Confession was essentially a 'church theology', but not in the sense of the term as understood and criticised in the Kairos Document, as the late Steve de Gruchy pointed out in comparing the ecclesiologies implicit in the two documents (de Gruchy 2015:244-255). This was also the stance of the Barmen Declaration, but Belhar went a step further in taking the 'preferential option of the poor', thereby insisting that the 'true church' was not just non-racial but also taking the side of 'the people' who were marginalised, in the struggle for justice (Smit 1984:7-32). It was precisely in doing so that Belhar and Kairos found themselves on the same side despite their ecclesiological differences. The kairos moment was equally a status confessionis.

This development reflects the influence of Bonhoeffer's later prison theology in which he criticised the Confessing Church and, by implication the Barmen Declaration, because in following Barth's theology of revelation it became 'entrenched behind the notion of the "faith of the church",' (Bonhoeffer 2010:502) and stood 'up for the "cause" of the church', and 'against the world' (Bonhoeffer 2010:500). In the process, Jesus 'disappeared from sight' (Bonhoeffer 2010:500). In saying this Bonhoeffer was not referring to the liberal 'Jesus of history', or the Jesus of popular piety, for they were doing well in the German church; he was speaking about the Jesus who, as the eschatological Son of Man, stands in solidarity with the victims of the earth, the Jesus who, as the Christ, exists for others. This, as Bonhoeffer's friend Eberhard Bethge immediately recognised, also had to do with the prophetic responsibility of the church ${ }^{3}$ (Bonhoeffer 2010:413). Which led Bonhoeffer to elaborate further and say that the 'church is church only when it is there for others' (Bonhoeffer 2010:503). The implications of this, as Bonhoeffer then described them, were far-reaching. In short, if Jesus is the prophet who is more than a prophet, the church cannot be less than a prophet in obeying him as Lord. This highlights the need for a 'prophetic ecclesiology' that is able to respond to contemporary kairos moments as moments in which the church not only has to confess its faith anew (status confessionis) but, in doing so, confront new expressions of 'state' and 'church' theologies.

\section{A prophetic ecclesiology}

A common complaint about the ecumenical church in South Africa is that while it had exercised a prophetic ministry against apartheid, after 1994 it withdrew from critical public engagement and returned to 'church business' as usual.

3.In a letter dated 3 June 1944 . 
Even kairos theologians, who had aligned themselves with the 'liberation movement' as God's instrument for ending apartheid, now entered public life whether in government or education. Within a few years a new 'state theology' began to emerge in support of the state and its policies, and 'church theology' continued to reign within congregations and denominations, but now in both the 'white' and the 'black church'. There were charismatic prophets aplenty, but the voice of the prophets of social justice was at best muted. There was little sense that the church was not only to pray, but also to be prophetic without ceasing. If 1994 was a kairos moment, it was not one that called for uncritical solidarity with the newly elected government and the task of nation building, but for the ongoing confession of Christ as Lord.

The Nicene Creed speaks of the church as one, holy, catholic and apostolic but not specifically as prophetic unless 'apostolic' is understood, as it has been at times, inclusive of prophetic and not just hierarchical leadership. Although there is only one passing reference to the prophetic tradition in the Documents of Vatican II among the many references to liturgy and the like, Karl Rahner, writing from a Catholic perspective, insists that the prophetic element should shape the cultic (Rahner 1975:1289). Certainly from a Reformed point of view, the prophetic is a mark of the 'true church'. Having said that, however, the church as prophet is not generally part of ecclesial consciousness, and too often its own prophets are disregarded or rejected. This ignores the ecclesiological implications of the prophetic office of Christ. As Rahner again reminds us, 'the church itself is the permanent presence of the word of the prophet, Jesus Christ' (Rahner 1975:1288). This ministry embraces everything that helps 'make the message of Jesus new, relevant and actual in each changing age', whether this has to do with the renewal of the church or critical witness within society (Rahner 1975:1288).

Mark's gospel begins with Jesus' prophetic announcement that the 'kairos has come, the kingdom of God is at hand' (Mk 1:14-15). In Luke-Acts this prophetic mission of Jesus (Lk 4:16-21) is directly applied to the calling of the church after Pentecost (Ac 2:14-21). What Jesus began to do as charismatic healer and prophet, the church, endowed with his Spirit, was meant to continue. But increasingly in the primitive church, prophecy refers to either charismatic proclamation or to predicting the Second Advent of Christ, rather than to the proclamation of God's justice. This did not mean that the church had no social conscience, but it was after all a small Jewish sect in a very hostile environment that lived in hope of the coming of God's reign of justice in the imminent future. The prophets had fulfilled their mission in predicting the coming of the Messiah; their message of social justice belonged to a previous dispensation or anticipated the next. It was not addressed to the here and now. In addition, nothing is said about Jesus the prophet in the Christological debates that led to the formulation of the Nicene Creed, ${ }^{4}$ even though the prophets along with the

4.There is, for example, no reference to Christ as prophet in Grillmeier's (1975) definitive study. apostles were earlier acknowledged as the foundation stones of the church of which Christ was the chief corner-stone (Ephesians 4:11-12).

This silencing of the prophetic imagination was due as much to social forces and political factors as it was to theological considerations. The unity of Christendom demanded an imperial 'state theology' that was subservient not subversive. This meant censoring millenarian ideas, and rejecting movements such as Montanism. As David Aune writes: 'With the institutionalisation of Christianity and the rationalisation of its authority structures, prophecy became redundant as well as dysfunctional' (Aune 1983:33). Paul's fear came true: the Spirit was quenched and the words of the prophets despised (I Th 5:19-20).

The suppression of the millennial and charismatic prophetic spirit drove it underground but it continued to erupt into prominence in the course of subsequent history given the right circumstances. In doing so it took many different forms, and it is as strong in our day as it has ever been, especially within those sections of the church where charismatic gifts are encouraged or in those where a dispensationalist interpretation of the Bible predominates. The latter has led to a revival of prophetic teaching about the End Times which now provides the theological rationale for Christian Zionism in its uncritical support for the State of Israel and the policy of the United States towards Israel (Ateek 2014:217-220). For this reason, as within the global kairos movement, the prophetic critique of 'state theology' has been expanded into a critique of 'imperial theology', namely those theologies that justify hegemonic global exploitation and oppression, something that mirrors the Roman Empire in first century Palestine (Raheb 2014).

That Premillenial prophecy should have become a servant of 'imperial theology' is surely an irony (Burge 2014). But the truth is that 'prophetic' now only means, for many Christians, being able to 'read the signs of the times' in terms of the Second Coming of Jesus and the fate of modern Israel. It does not refer to the struggle for justice and the liberation of the oppressed. As a result, prophecy and 'prophetic theology' have once again become highly contested terms. Equally problematic is the fact that Old Testament covenantal promises are uncritically applied to the modern State of Israel even within so-called 'mainline churches' (Braverman 2010). Two key issues are involved. The first has to do with the interpretation of the Old Testament for the life and witness of the church today, and the second, with discerning the nature of the kairos and the appropriate response.

Bonhoeffer, following Barth and Wilhelm Vischer in opposition to the German Christian rejection of the Old Testament, emphasised that it was inseparable from the New Testament but interpreted it Christologically (Kuske 1976). However, in his prison letters Bonhoeffer argued that the New also had to be understood in the light of the Old (Bonhoeffer 2010:367). For him this meant in a 'worldly' and holistic sense rather than a religious and individualistic one. 
'Does the question of saving one's soul even come up in the Old Testament?' Bonhoeffer asked. Isn't it rather that God's righteousness and kingdom on earth is the center of everything?'

What matters is not the beyond, but this world, how it is created and preserved, is given laws, reconciled and renewed. What is beyond this world is meant, in the gospel, to be there for this world not in the anthropocentric sense of liberal, mystical, pietistic, ethical theology, but in the biblical sense of the creation and the incarnation, crucifixion and resurrection of Jesus Christ. ... the concepts of repentance, faith, justification, rebirth, and sanctification should be reinterpreted in a 'worldly' way - in the Old Testament sense and in the sense of John 1:14. (Bonhoeffer 2010:367)

In other words, this means in the sense of the prophetic Word embodied in Jesus the Christ who redeems and reconciles the world through restoring God's reign of global justice (de Gruchy 2002:51-56; Marshall 2001). And insofar as the church is the body of Christ, it too is called to become the embodiment of the prophetic Word.

In a sermon written in prison for the baptism of his godson Dietrich Bethge, Bonhoeffer anticipated that one day the time would come when there would be prophets in the mould of Jeremiah who would again speak the Word of God 'in such a way that the world is changed and renewed'. It will be proclaimed, he said:

in a new language, perhaps quite nonreligious language, but liberating and redeeming like Jesus' language, so that people will be alarmed, but overcome by its power - the language of a new righteousness and truth, a language proclaiming that God makes peace with humankind and that God's kingdom is drawing near... Until then, the Christian cause will be a quiet and hidden one; but there will be people who pray and do justice and wait for God's own time. (Bonhoeffer 2010:437)

It may be much too pretentious to claim that the growing global kairos movement is the sign that Bonhoeffer longed for but I have no doubt that Bonhoeffer would have identified with the Kairos-Palestine Document (2009) and regarded it as speaking 'the language of a new righteousness and truth' (de Gruchy 2012:67-80). There are several passages in KairosPalestine that specifically refer to the prophetic character of the church that resonate with Bonhoeffer's theology:

Our Church is a Church of people who pray and serve. This prayer and service is prophetic, hearing the voice of God in the present and future ...

The mission of the Church is prophetic, to speak the Word of God courageously, honestly and lovingly in the local context and in the midst of daily events. If she does take sides, it is with the oppressed, just as Christ our Lord stood by the side of each poor person ...

The mission of the Church is to proclaim the kingdom of God, a kingdom of justice, peace and dignity ... (Kairos-Palestine 2019)

This is undeniably a 'church theology', but a prophetic church theology rather than that rejected by the original Kairos Document. And it was recognised as such when it was endorsed by all the Patriarchs and Heads of Churches in
Jerusalem for whom the Kairos-Palestine is a faithful testimony to the gospel of the crucified and risen Christ. Such ecumenical consensus was never achieved by the Kairos Document in South Africa despite considerable ecumenical solidarity in the struggle against apartheid.

With this in mind, there was a debate at the 30th Kairos Anniversary about whether 'church theology' was the appropriate term to describe those who pursued 'cheap reconciliation'. Some church leaders who identified with its intention even refused to sign the Kairos Document back then because they felt that the phrase 'church theology' was wrongly used. It is also noteworthy that the term is not used in Kairos-Palestine. So in retrospect it would have been better to speak about a 'false church theology', because a 'true church theology', as Belhar righty discerned, must be prophetic. After all the kairos theologians were mostly pastors and priests, they were also part of the ecumenical church and, within the broader community of anti-apartheid activists, they were representative of the church. Moreover, the people' with whom they stood in solidarity were 'church people'; the 'black church' was their terrain. They were 'prophetic church theologians'.

A question that does arise, however, is whether there can be a prophetic ecclesiology that would comfortably fit all the ecclesiological paradigms that have traditionally shaped the ecclesial consciousness and practice of those involved in the global kairos movement. We have already noted that there were differences in this regard between the Belhar Confession (with Barmen in the background) and the Kairos Document, and there are likewise between the latter and the Kairos-Palestine Document. Belhar and Barmen were decidedly Reformed in their ecclesiology while the Kairos Document may have been more Catholic, although Pentecostals as well as Reformed were involved in drafting it. So it could be argued that there was no attempt to achieve consensus in terms of what the church should be in essence, only a consensus in terms of the failure of the mainline churches to be prophetic. 'Church theology', in other words, was not a description of the church, but a reference to its witness. For that reason, theologians of different confessional stripes could readily identify with it who might otherwise have disagreed on the nature of the church. The same is true for the Kairos-Palestine Document which was endorsed by church leaders ranging from various Eastern and Oriental Orthodox Churches, to Lutherans and Reformed.

The fact is, ecclesiology understood in traditional terms was not the issue - prophetic witness was. Given the church situation in Palestine and more generally in the Middle East, it would clearly have been unhelpful to reject 'church theology' because of the inevitable misunderstanding it would provoke, as it did among some church leaders in South Africa, most notably Archbishop Desmond Tutu. In short, it would be naive, whether in South Africa or more globally, to expect that an ecumenical prophetic ecclesiology would solve fundamental ecclesiological issues (hierarchy, catholicity etc.). But that has not prevented Christians across 
the confessional spectrum from jointly recognising the need for a prophetic ministry that needs to be exercised ecumenically. This much has been clearly acknowledged by the most recent statement of Faith and Order within the World Council of Churches which was prepared by theologians representing all the confessions involved in the Kairos movement (Faith and Order 2013:37).

This is a major ecumenical achievement because the silencing of prophets, or the attempt to do so, as was true in biblical times and has since been true throughout Christian history, has been a sad commentary on the failure of the Christian church to witness faithfully to the reign of God in history. Those prophets who have arisen in our own time, from Martin Luther King Jr. in the United States to Beyers Naudé in South Africa, have all been shunned or silenced if not killed, and those who are witnessing to justice in many parts the world at this time, not least in Israel and Palestine, are suffering likewise. Jesus wept over Jerusalem because it did not 'recognise the kairon of God's visitation' and understand 'what makes for peace' (Luke 19:41-44). How tragic it is that the church so often honours its prophets only after the kairos moment has passed, and with it the opportunity to change direction and avoid disaster. That is why it is of fundamental importance to develop an ecumenical prophetic ecclesiology and consciousness that enables the church to recognise the kairos when it occurs, and so hear the word of the prophets before it is too late. The present global kairos is surely the time to remember the call of Moses to the Hebrews in the desert: 'Would that all the Lord's people were prophets!' (Nm 11:29).

\section{Acknowledgements Competing interests}

The author declares that he has no financial or personal relationships which may have inappropriately influenced him in writing this article.

\section{References}

Ateek, N.S., 2014, 'A concluding theological postscript', in D.E. Wagner \& W.T. Davis (eds.), Zionism and the Quest for Justice in the Holy Land, Wipf \& Stock, Eugene, OR.

Aune, D.E., 1983, Prophecy in early Christianity and the ancient mediterranean world, Eerdmans, Grand Rapids, MI.

Barth, K., 1956, Church dogmatics: The doctrine of reconciliation, vol. IV/1, T\&T Clark, Edinburgh.

Barth, K., 1958, Church dogmatics: The doctrine of reconciliation, vol. IV/2, T\&T Clark, Edinburgh.

Barth, K., 1975, Church dogmatics: The doctrine of the word of God, vol. 1/1, T\&T Clark, Edinburgh.

Barth, K., 1976, 'Jesus Christ and the movement for social justice', (1911) in K. Barth \& R. Politics, (ed.), George Hunsinger, pp. 19-46, Westminster Press, Philadelphia, PA.

Barth, K. \& Eduard T., 1964, Revolutionary theology in the making: Barth-Thurneysen correspondence 1914-1925, Epworth Press, London.

Bonhoeffer, D., 2010, 'Letters and papers from prison', J.W. De Gruchy (ed.), Dietrich bonhoeffer works, p. 52, vol. 8, Fortress Press, Minneapolis, MN.
Bosch, D., 1983, 'Nothing but a Heresy', in J.W. de Gruchy \& C. Villa-Vicencio (eds.), Apartheid is a Heresy, pp. 24-38, David Philip, Cape Town.

Brown, C., 1978, 'Prophets', C. Brown (ed.), Dictionary of New Testament theology, vol. 3, Exeter, Paternoster Press, Devon.

Brueggemann, W., 1997, Theology of the Old Testament: Testimony, dispute, advocacy, Fortress Press, Minneapolis, MN.

Buber, M., 1960, The prophetic faith, p. 96, Harper Torchbooks, New York, NY.

Burge, G.M., 2014, 'Evangelicals and Christian Zionism', in D.E. Wagner \& W.T. Davis (ed.), Zionism and the Quest for Justice in the Holy Land, pp. 175-190, Wipf \& Stock, Eugene, OR.

Cloete, G.D. \& Smit, D.J., (eds.), 1984, A moment of truth: The confession of the Dutch reformed mission Church, 1982, Eerdmans, Grand Rapids, MI.

Cochrane, A.C., 1976, The Church's confession under Hitler, Pickwick Press, Pittsburgh, PA. Cohn, N., 1970, The pursuit of the millennium, Oxford University Press, New York, NY. De Gruchy, J.W., 1985, 'Christians in conflict: The social reality of the South African Church', Journal of Theology for Southern Africa 51, 16-26.

De Gruchy, J.W., 2002, Reconciliation: Restoring justice, SCM, London.

De Gruchy, J.W., 2004, The Church struggle in South Africa: 25th Anniversary Edition, SCM, London.

De Gruchy, J.W., 2012, 'Bonhoeffer's legacy and Kairos-Palestine', Journal of Theology for Southern Africa 143, 67-80.

De Gruchy, S., 2015, 'From Kairos to Belhar: On being Church in a time of AIDS', in B. Haddad (ed.), Keeping body and soul together: Reflections by Steve de gruchy on theology and development, pp. 244-255, Cluster Publications, Pietermaritzburg, RSA.

Dunn, J.D.G., 1975, Jesus and the spirit, SCM, London.

Ericksen, R.P., 1985, Theologians under Hitler, Yale University Press, New Haven, CT.

Faith and Order, 2013, The Church towards a common vision, Faith and Order Paper No. 214, World Council of Churches, Geneva.

Gramsci, A., 1971, Selections from prison notebooks, Lawrence and Wishart, London. Grillmeier, A., 1975, Christ in Christian tradition, vol. 1, John Knox Press, Atlanta.

Heschel, A.J., 1962, The prophets, Harper \& Row, New York, NY.

Hirsch, E., 1933, Das kirchliche Wollen der deutsche Christen, Berlin.

Horton, W.M., 1952, 'Tillich's role in contemporary theology', in C.W. Kegley \& R.W. Bretall (eds.), The theology of Paul Tillich, 26-49, Macmillan, New York.

Jeremias, J., 1971, New Testament theology I: The proclamation of Jesus, SCM, London.

Kairos-Palestine, 2009, A Moment of Truth: A Word of Faith, Hope and Love from the Heart of Palestinian Suffering', A document drafted by Palestinian Christians and endorsed by the Patriarchs and Heads of Churches in Jerusalem, viewed n.d., from http://www.kairospalestine.ps

Kuske, M., 1976, The Old Testament as the book of Christ: An appraisal of Bonhoeffer's interpretation, Westminster, Philadelphia, PA.

Mark B., 2010, Fatal embrace: Christians, Jews, and the search for peace in the Holy Land, Synergy Press, Austin, TX.

Marshall, C.D., 2001, Beyond retribution: A New Testament vision for justice, crime, and punishment, Eerdmans, Grand Rapids, MI.

Moodie, T.D., 1975, The rise of Afrikanerdom: Power, apartheid and the Afrikaner civil religion, p. 1, University of California Press, Berkeley, CA.

Nolan, A., 1994, 'Kairos theology', in J. de Gruchy \& C. Villa-Vicencio (ed.), Doing theology in context: South African perspectives, 212-217, David Philip, Cape Town.

Raheb, M., 2014, Faith in the face of empire: The Bible through Palestinian eyes, Diyar, Bethlehem, Palestine.

Rahner, K., 1975, 'Prophetism', in K. Rahner (ed.), Encyclopedia of theology: A concise Sacramentum Mundi, pp. 1296-1289, Burns \& Oates, London.

Schillebeeckx, E., 1979, Jesus: An experiment in Christology, Collins, London.

Scholder, K., 1987, The Churches and the Third Reich: 1918-1934, SCM, London.

Smit, D., 1984, 'What does status confessionis mean?', in G.D. Cloete \& D.J. Smit (eds.), A moment of truth: The confession of the Dutch reformed mission Church, 1982, Eerdmans, Grand Rapids, MI.

The Kairos Document, 1986, The Kairos Document, Institute for Contextual Theology, Johannesburg.

Tillich, P., 1957, The protestant era, University of Chicago Press, Chicago, IL.

Tillich, P., 1963, Systematic theology, vol. 3, University of Chicago Press, Chicago, IL.

Villa-Vicencio, C. (ed.), 1988a, Reading Karl Barth in South Africa, Eerdmans, Grand Rapids, Ml.

Von Rad, G., 1972, The message of the prophets, SCM, London. 